\title{
British and American culture sympathy establishment and to English
}

\section{study influence}

\author{
Xiao li
}

Harbin University of Commerce, Harbin, Heilongjiang, 150028

\begin{abstract}
Keywords: British and American culture; Identity; To learn English
\end{abstract}
\begin{abstract}
Ignore or even hostile to exist in the part of college students, the author of this paper to study the phenomenon of English and its culture, first of all, this paper expounds the necessity of learning English and its culture, illustrates the significance of cultural identity, then in English teaching is discussed how to help college students to establish identity of British and American culture, and the establishment of cultural identity which influence on English learning, thus has certain instructive and practical.

Foreign language teaching should be combined with the target language culture and native culture, has become the consensus of foreign language teaching today. However, due to various reasons, some hard questions for learning English and its culture[1],They thought "in China, western culture is to overflow with situational, influenced by the Chinese spirit and consciousness, changing the social customs and cultural structure of the Chinese people.This but the phenomenon of western culture followed, people Jue called is a Chinese 'banana' -- in addition to the skin is yellow, the heart and nature is the "white" Even people think[2],"Difficult to find any country in the world such as China to other countries' language as their language, their own language as a foreign language” 。

"Blind learning foreign language is not only greatly consumed energy of the Chinese people, and weaken the national pride and identity, detrimental to the development of Chinese culture" 。

"English learning has shaken rather, consumes the manpower and material resources, financial resources, more weakened the national culture foundation, played down the national consciousness, eroding national cohesion, cultivate and encourage the obsequious beauty and beautiful mood" 。

These questions and criticisms to cultivate college students' correct attitude to learn English the bad effect caused by the part of the original English foundation is poor, learning enthusiasm is not high, breeds prejudice against British and American culture and resistance.This hostility to learn English and its culture phenomenon, affect to the college English teaching, the nature not to mention make a batch of concentrated outside of culture longer than a modern "global village".In foreign language teaching in China, therefore, the main body of English teaching, how to help college students establish identity of British and American culture, and the establishment of cultural identity which influence on English learning, still appear very necessary.
\end{abstract}

\section{The necessity of learning English and its culture}

May be because of the effect of English spread to the world, its culture worldwide, this position of strength and cultural hegemony makes some weakness in language and culture of country and nation, hate learning English, in an attempt to resist British and American culture, but they have to learn English.

English is the United Kingdom, the United States, Canada, Australia, New Zealand, South Africa and many countries of the main medium of communication, is the official language in about 
45 countries, and also is one of the working languages in the UN.Under the Internet popularization and the trend of globalization, the influence of English is more and more big, about $50 \%$ of the company's business in Europe with the help of English, 75\% of the world's correspondence and $80 \%$ of the information transmission depends on English, it has become a language spoken by the largest number of people in addition to the Chinese.In the 21st century today, English is the international language, so to speak. Leave the English, is to cut off contact with the whole world, the free world outside will go out of the world.

Countries in the world is not separate areas, but a "global village". To blend in this "global village", understood that this international language is very necessary to use English, understand English load by the cultural information also become equally important.

Especially the students who have different cultural background, if you can't deeply understand the culture of the english-speaking countries, you can't understand some words concrete has pointed out, it is not easy to accurately grasp the meaning of the author or speaker.

SleepingBeauty, for example, a is not only refers to a certain character of proper nouns, it has become a language to describe someone sleep, such as JustlookatSleepingBeautythere!(The man is really sleep well!)

\section{The establishment of the British and American cultural identity}

Now that you must learn English, as an international language and the culture of the two sides had to teach, so how to teach effectively, is a subject in front of us.

Native English speakers or English as the official language of countries to dozens more, single on the former, the British culture, American culture, Canada, Australia, New Zealand culture, culture of South Africa, etc.

As a result of the related culture too much, and limited time and condition, English teaching can't, don't carry too much content.

Therefore, can only choose English world mainstream culture as the main teaching content, to do this is to cater to cultural hegemony, but after all, the us and the UK is far higher than other developed countries, there are a lot of things worth learning and using for reference.In Chinese has not been popular in the world, has not yet been master of international academic mainstream scholars, use English to promote China to the world he is still an expedient measure.

The real task of college English teaching is to let students to recognize the limitations of native culture and English culture, break through the single cultural stereotype brings to the communication barriers, fully express their views, fully understand each other's ideas, in order to achieve equality and meaningful communication.And the fundamental purpose of English teaching is not the acquisition of English culture, but the development of college students express their culture and ideas of communicative competence.

And the fundamental purpose of English teaching is not the acquisition of English culture, but the development of college students express their culture and ideas of communicative competence.

And the fundamental purpose of English teaching is not the acquisition of English culture, but the development of college students express their culture and ideas of communicative competence.Because of this, the sea was the communicative competence as part of the culture ability (culturalcom2petence)[3]。

To develop students' cultural field of vision, cultivate their cross-cultural awareness, to develop their cultural ability, improve their appropriateness to use English, it should be through rich and colorful activities, as well as a variety of ways, guide them to understand and familiar with, recognize, accept and appreciate British and American culture, the good and discard the dregs, the 
correct attitude towards the foreign culture, let they have tolerance and acceptance of the world culture, especially the front of British and American culture.That in learning English and its culture have resistance, is particularly important.

Help college students to build up of British and American culture identity, can make the body of the English teaching has good psychological preparation status, thus smoothly to lay a solid foundation for the teaching, also provide reliable guarantee for the final results of learning.

Culture teaching content, but specifically, "culture teaching contents include language communication, nonverbal communication, social customs, human relations and values such as". Therefore, to strengthen the university student to the British and American culture identity, can from the following several aspects:

(1)Identify cultural differences in language communication

Language communication aspects of British and American culture teaching vocabulary, idioms and grammar, discourse, rhetoric, etc. Teachers' teaching, in addition to basic routine, to college students with clear words, idioms, contained in the discourse of cultural connotation, to be noted cultural factors to understand the word meaning and appreciate the importance of intention.For example, the British said in M25 highway (25), students may be able to infer from the context that is an important way of Britain. However, there is a little do they know? It is well known in the UK, that is --, M25 also refers to the traffic congestion, traffic very slow. As another example, the word "cracker" refers to "firecracker" in British English, but "biscuit" in American English.To understand this, students would not be difficult to imagine an American said to his English friend "Wouldyouliketoeatsomecrackers?" When friends of facial expression。

This cultural difference is belong to the English language itself, as well as between English and Chinese.

"Eastwind", for example, have the same the original meaning in English, but Chinese symbol in the Middle East wind "warmth and vitality," the east wind in the UK, contains the meaning of "cold and sad".

It should be clear to all students, because from continental Europe blew in east wind is the wind, so the British people prefer the west wind. Understand the meaning of these words, it is natural for students to understand why the famous British poet Shelley to the west wind in "TheOdetotheWestWind" much praise.

(2)To clarify the cultural traits of nonverbal communication

Nonverbal communication in British and American culture teaching content more, involving expressions, eye contact, gestures, posture, body, etc.College students understand this aspect of a variety of cultural traits, can be in a relationship and British and American people to read their body language, understand their intentions.

For foreigners, the British and the americans in a conversation is different from the body, the British people always keep a certain distance to each other, and americans are near to each other, are very warm and affectionate.Visible, when we and the British and American people should follow their customs, keep the corresponding distance.

Look at this example: The wedding ring is worn on The third finger of The left hand, we should guide them to think about: wedding ring should put on The ring finger, why in America and Britain are put on The "thethirdfin2ger"?Thumb in the original English are called thumb, and the rest four fingers called fin2gers, from the index finger, middle finger, ring finger to the little finger of the first finger, the second finger and third finger and fourth (orlast) finger. So, why single to wear a wedding ring on the fourth finger?This is a thought-provoking question. Ground that westerners believe that ring finger blood vessels and the heart is interlinked directly, can put a ring 
on his ring finger means that many will love in my heart.

\section{The influence of cultural identity in English learning}

College students just adult, wet behind not deep, strong plasticity, teachers inspire and guide can make their experience or choose to go to British and American culture; In the process of experience through reflection, assimilation, or conform to, will be emotional experience internalizes for own idea; In the real cultural practice, their experience through externalization and constantly adjust, can be continuously strengthened.College students' cultural identity, is such a real or close to the real language environment to experience the process of English culture and constantly adapt to. "The second language study involves the second cultural study, therefore the second language study is a culture moves in( acculturation), namely adjusts self-adapts the new cultural environment process”。

"The research adapts which to human's culture indicated that, the human from is born all intends or accidentally each kind of social group's faith, the behavior standard and the value orientation influence to the life end which accepts him through the observation and the practice to locate.As a result of this cultural adaptation of covertness, complexity and objective of the people tend to overlook the fact that all the familiar not external teaching, but the outcome the products of a culture of the Surrounding Environment " 。Once the university student establishes to the British and American culture sympathy, they can eliminate the former prejudice and be hostile to, the academic society distinguishes, the admission and the containing other country culture, can develop own unceasingly cultural field of vision, sharpens own gradually cultural ability, thus achieves English teaching the final goal 。

Although the present university English teaching Chinese-adapted teaching has become common practice, was still unavoidable the class in to be fragmentary and to be superficial, waits for toward depth digging, otherwise affected the university student language culture ability on the possibility the further enhancement.But so long as our each teacher in the ordinary teaching practice, in the attention excavation existing teaching material cultural element, and at the right moment makes up insufficiency of the teaching material compilation, At the same time, actively guide the students in the relevant reading, cumulatively, the latter, can finally to teach students how to build up a culture of British and American Tower.

\section{References :}

[1].Xu Li-Sheng, Wuliping.Reflection on cultural acquisition in foreign language teaching [J].Foreign language in China, 2006, (4):78

[2]Wang Zhenya: In the area of cross-cultural exchanges for the purpose of teaching language [M].Beijing: Beijing Language and Culture University Press, 2005. 2

[3]Gao Wen. Situational learning and situational awareness [J]. Education development research, 2001, (8):31 